KOŚCIÓŁ I PRAWO 8(21) 2019, nr 1, s. 249-270

DOI: http://dx.doi.org/10.18290/kip.2019.8.1-16

\author{
Marcin Konarski
}

\title{
REFORMY ORGANIZACJI \\ KOŚCIOŁA RZYMSKOKATOLICKIEGO WE FRANCJI W LATACH 1789-1791
}

\section{WPROWADZENIE}

Wydarzenia, jakie miały miejsce we Francji podczas Rewolucji francuskiej budzą wciąż po ponad dwustu jeszcze latach od jej zakończenia, zarówno emocje, jak i kontrowersje. Jednym z zagadnień, które do dnia dzisiejszego stanowi przedmiot sporów, jest to odnoszące się reform spraw wyznaniowych i organizacji kościelnej, które ostatecznie zostały ukończone zawarciem - już w okresie panowania Napoleona Bonaparte - konkordatu między rządem francuskim a Jego Świątobliwością Piusem VII w dniu 15 lipca 1801 r. (26 messidora roku IX) [Mathieu 1903; Latreille, Palanque, Delaruelle, i Rémond 1962, 161-78; Rudé 1966, 238-41; Kumor 1985, 194-97; Banaszak 1991, 48-49].

Doniosłość tego momentu dziejowego niech potwierdzi fakt, że umowa między papieżem Piusem VII a rządem francuskim była pierwszą tego rodzaju umową zawartą przez państwo konstytucyjne ${ }^{1}$. W dniu 15 kwietnia 1802 r. umowa ta została oficjalnie ogłoszona, wywołując ogromne poruszenie w całej ówczesnej Europie. Konkordat tzw. napoleoński obowiązywał we Francji przez 100 lat, aż do uchwalenia ustawy o rozdziale kościołów od

DR MARCIN KonARSKI - adiunkt, Katedra Administracji, Wydział Nauk Społecznych i Administracji Wyższej Szkoły Menedżerskiej w Warszawie; adres do korespondencji: ul. Kawęczyńska 36, 03-772 Warszawa, Polska; e-mail: marcin.konarski@wsm.war szawa.pl; https://orcid.org/0000-0001-8791-884X

${ }^{1}$ Szerzej postanowienia tego konkordatu zob. Wasilewicz 2017, 61-65. 
państwa w dniu 9 grudnia 1905 r. [Banaszak 1991, 257-59]2. Podkreślić należy, że to właśnie na konkordacie napoleońskim będą następnie wzorować się później liczne konkordaty zawierane w XIX i XX w. przez Stolicę Apostolską z innymi państwami ${ }^{3}$.

Zanim jednak doszło do zawarcia konkordatu w 1801 r., Francja była areną trwającej ponad dziesięć lat walki religijnej, która kosztowała życie tysięcy osób po każdej ze stron tego konfliktu ${ }^{4}$.

Ze względu na ramy niniejszego opracowania, nie uda się dokonać analizy poszczególnych reform stosunków wyznaniowych w trakcie całego tego ponad dziesięcioletniego okresu Rewolucji, wobec czego rozważania dotyczyć będą tylko niewielkiego okresu czasu, jaki przyjęliśmy za przedmiot badawczy, a mianowicie - pierwszego okresu zmagań rewolucyjnej Francji z reorganizacją Kościoła rzymskokatolickiego, obejmującego czas od uchwalenia pierwszych aktów normatywnych regulujących wzajemny stosunek państwa i Kościoła w 1789 r. do czasu przyjęcia przez Konstytuantę (Zgromadzenie Prawodawcze) konstytucji cywilnej duchowieństwa w 1790 r. Ten krótki, wydaje się, okres dwóch lat, uznaje się jednak za okres o najbardziej „rewolucyjnym” charakterze, i to nie tylko w zakresie wzajemnych stosunków między władzą świecką a władzą duchowną. W tym okresie bowiem Francja porzuca wielowiekową tradycję ustrojową absolutyzmu i przekształca się w monarchię konstytucyjną. W okresie tym nie dochodzi do żadnych gwałtownych ataków na duchowieństwo mających charakter fizycznej przemocy, prześladowań i rodzących po jego stronie ofiary w ludziach. Pomimo tego, że Kościół stanowił przedmiot gwałtownych ataków, zazwyczaj nie ma to objawów antyreligijności [Markov i Soboul 1984, 139; Baszkiewicz 1993, 280] ${ }^{5}$.

${ }^{2}$ Loi du 9 décembre 1905 concernant la séparation des Eglises et de l'Etat, https:// www.legifrance.gouv.fr [dostęp: 7.11.2018]; tekst polski w: Kościelne prawo publiczne. Wybór źródet, red. M. Sitarz, M. Grochowina, M. Lewicka, A. Romanko, P. Wierzbicki, Wydawnictwo KUL, Lublin 2012, s. 846. Szerzej zob. Wasilewicz 2013, 201-204; Duguit, Monnier, i Bonnard 1952, 331; Lecomte 1906.

${ }^{3}$ Szerzej na temat okoliczności dojścia Napoleona do władzy, zob. Tarle 1946, 53-64; Konarski 2017b, 54-57.

${ }^{4}$ Najwięcej ofiar pochłonęły tzw. masakry wrześniowe, do których doszło w dniach 2-6 września 1792 r. w Paryżu, zob. Barruel 1815, 64n.; Le Bon 1899, 129-34; Szelągowski 1934, 501-29; Thompson 1937a, 383-92; Mezzadri 2007, 120-23; Nowak 1999, 7-8.

${ }^{5}$ A. Barruel przytacza wypowiedz G.H. de Mirabeau z dnia 5 maja 1789 r., który miał powiedzieć: „Jeżeli chcecie rewolucji, trzeba nam zacząć od dekatolizowania Francji”, zob. Barruel 1815, 12-13; por. Szelągowski 1934, 239; Baszkiewicz 1989b, 66. 
Pamiętać również przy tym należy, że reformy społeczne i polityczne okresu Rewolucji francuskiej - przeprowadzone przez trzy wielkie ciała prawodawcze tego okresu - stanowią wspólne wielkie dziedzictwo cywilizacyjne świata, będąc podłożem niepodważalnych wartości o charakterze społecznym, politycznym i moralnym. Przecież to właśnie ustawodawstwu rewolucyjnej Francji zawdzięczamy powszechną oświatę i wolność nauczania, kształtowanie postaw, wiedzy obywatelskiej i moralności publicznej, oświatę kobiet, zreformowanie uniwersytetów, opiekę socjalną i zdrowotną państwa, wolność wyznania, równość wobec prawa, usunięcie przywilejów stanowych z urzędów, z wojska i z organów przedstawicielskich i samorządowych, sądownictwo powszechne i administracyjne ${ }^{6}$.

Nie bez powodu Jan Paweł II podczas Mszy św. na lotnisku Le Bourget w Paryżu w 1980 r. wypowiedział słynne, lecz przemilczane niestety przez znaczną część badaczy, słowa oddające hołd myśli ludzkiej okresu Rewolucji francuskiej, wypowiedziane w duchu pojednania i poszanowania, które potwierdzają znaczenie dziedzictwa rewolucyjnej Francji dla świata i Kościoła: „Ileż zdziałali synowie i córki, waszego narodu dla poznania człowieka, aby go wyrazić w sformułowaniach jego nienaruszalnych praw! Wiadomo, jak ważne miejsce zajmuje w waszej kulturze, w waszej historii idea wolności, równości i braterstwa. W gruncie rzeczy są to idee chrześcijańskie. Mówię to ze świadomością, że ci, którzy pierwsi tak sformułowali ten ideał, nie mieli na myśli przymierza człowieka z odwieczną mądrością, ale chcieli działać dla niego [człowieka - M.K.]”7.

${ }^{6} \mathrm{Na}$ temat dorobku reformatorskiego rewolucyjnych zgromadzeń prawodawczych we Francji, zob. m.in. Kaczyńska i Piesowicz 1977, 236-37; Baszkiewicz 1999, 333-36; Konarski 2016, 44-46.

${ }^{7}$ „On sait la place que l'idée de liberté, d'égalité et de fraternité tient dans votre culture, dans votre histoire. Au fond, ce sont-là des idées chrétiennes. Je le dis tout en ayant bien conscience que ceux qui ont formulé ainsi, les premiers, cet idéal, ne se référaient pas à l'alliance de l'homme avec la sagesse éternelle. Mais ils voulaient agir pour l'homme", https://w2.vatican.va/content/john-paul-ii/fr/homilies/1980/ documents/ hf_jp-ii_hom_19800601_parigi-francia.html [dostęp: 3.11.2018]; tekst polski w: Jan Pawet II. Dzieła zebrane. Tom II. Homilie i przemówienia z pielgrzymek - Europa. Część 2: Francja, Hiszpania, Portugalia, kraje Beneluksu, Wydawnictwo „M”, Kraków 2008, s. 60 . 


\section{DUCHOWIEŃSTWO FRANCUSKIE W PRZEDEDNIU WYBUCHU REWOLUCJI}

Analizując sytuację francuskiego Kościoła rzymskokatolickiego w przeddzień wybuchu Rewolucji [Desan 1990, 3-8], należy podkreślić, że wiara religijna we Francji była mocno zakorzeniona „w umysłach i sercach” [Baszkiewicz 1993, 275] ${ }^{8}$, a katolicyzm nie znajdował się zaś w odwrocie - jak zresztą przystało na kraj nazywany „pierworodną córką Kościoła”. Miały miejsce zarówno spadek liczby powołań wśród duchownych, jak i laicyzacja bractw religijnych, niemniej nie było to spowodowane jakąś wyjątkową lokalną tendencją $\mathrm{w}$ tym kierunku, ale raczej stanowiło przejaw oddziaływania prądów umysłowych XVIII w. [Latreille, Palanque, Delaruelle, i Rémond 1962, 17-37; Duby i Mandrou 1965, 436 ${ }^{10}$, które licznie znajdywały we francuskim Kościele rzymskokatolickim podłoże do rozprzestrzeniania.

Duchowieństwo, tworzyło we Francji przed Rewolucją pierwszy stan [Weber 2002, 228-33], obdarzony szczególnymi przywilejami, wybierający pierwszą z trzech izb stanów generalnych i wywierający przemożny wpływ na bieg spraw państwa ${ }^{11}$, co zresztą nie było wyłącznie specyfiką francuską. Zróżnicowanie wewnątrz stanu było nad wyraz silne przede wszystkim właśnie w granicach tego stanu. Zróżnicowanie takie nie było wyłącznie specyfiką stanu pierwszego [Barruel 1815, 17-19]. Przecież szlachta, stan drugi, również była silnie podzielona. Na szczycie tego stanu znajdowała się arystokracja, i chociaż nie była ona liczna (ok. 5 tys. rodzin), to jednak mająca przemożny wpływ na bieg spraw państwowych we Francji. Poniżej arystokracji znajdowała się szlachta rodowa (noblesse de race) i szlachta urzędnicza (noblesse de robe), zaś w skład uciążliwej politycznie dla króla szlachty dworskiej wchodziły osoby wywodzące się zarówno ze szlachty rodowej, jak

${ }^{8}$ Por. Faral 1969, 174-87.

9 Jan Paweł II, Wywiad dla „L'Osservatore Romano” i Radia Watykańskiego, w: Jan Pawet we Francji $i$ w siedzibie UNESCO 30 V-2 VI 1980. Homilie, przemówienia, orędzia, oprac. A. Podsiad, Warszawa 1984, s. 200.

${ }^{10}$ Przedstawiciele prądów umysłowych XVIII w. nie szczędzili Kościołowi jak i samej religii rzymskokatolickiej gorzkich słów, zob. m.in. Meslier 1955, 73n.; Wolter 1960, 235-310; Hazard 1972, 56-109.

${ }^{11}$ Od 1685 r. księża katoliccy mieli prawo publicznego wykonywania ceremonii religijnych, zaś religia katolicka posiadała status religii państwowej. Jak zwraca uwagę M. Żywczyński, „Opieka prawa, silne podstawy materialne, nieograniczona swoboda działania, stara tradycja katolicka, słabość prawna przeciwników - wszystko to dawało Kościołowi potęgę ogromną" [Żywczyński 1951, 9]. 
i urzędniczej [Kautsky 1905, 17-21] ${ }^{12}$. „(..) szlachta mieszkająca na wsi miała również swoją arystokrację i swoją herbową biedotę - szlachecki plebs żyjący na poziomie chłopów” [Chłopecki 1981, 83].

Liczba duchowieństwa we Francji przedrewolucyjnej jest ustalana „na oko i nie poparte naukowymi badaniami, przy czym liczby te poważnie różnią się między sobą" [Machlejd 1934, 35] ${ }^{13}$. Na przykład bezpośrednio przed Rewolucją na jeden zakon męski wypadało przeciętnie zaledwie niespełna 10 mnichów. Liczne były zakony, gdzie było zaledwie kilka osób [tamże, 37].

Wyższe duchowieństwo, szczególnie niektórzy arcybiskupi, biskupi i opaci, byli nadzwyczaj na owe czasy majętni [Kautsky 1905, 27-28]. Przodował wśród nich biskup Strasburga (był nim wówczas słynny przede wszystkim z tzw. afery naszyjnikowej kardynał Rohan) [tamże, 19; Carroll 2011, 13336], któremu przysługiwał tytuł księcia i hrabiego (landgrave) Alzacji, zaś

12 J. Chłopecki scharakteryzował szlachtę dworską (nobless de cour) w następujący sposób: ,jest niezadowolona z panujących stosunków, jest krytyczna, ironiczna, złośliwa wobec króla, choć wzorem klasycznych dworaków w jego obecności czołobitna i służalcza. Ale jej krytycyzm jest jałowy i bezskuteczny, jej aktywność obraca się tylko wokół własnych dochodów i utrzymania własnej pozycji w efekcie gry dworskiej. To samo odnosi się do wyższych kręgów duchowieństwa" [Chłopecki 1981, 83].

${ }^{13}$ Autor przytacza wyniki ustaleń poszczególnych badaczy w sposób następujący: Peuchet podaje 500 tys., Expilly 406 tys., Target 400 tys., Boiteau 200 - 250 tys., Rabaut Saint Etienne 200 tys., Moheau (ten jeden autor podaje liczbę kleru w 1778 r. 129 tys. mężczyzn i 64 tys. kobiet) 194 tys., Taine (a za nim Carré-Lavisse) 130 tys., P. de la Gorce 125 tys., Arthur Young 80 tys., Abbé Siéyès 80 tys., Talleyrand, biskup Autun na posiedzeniu Konstytuanty z dnia 10 października 1789 r. mówi o 80 tys. [Machlejd 1934, 35]. Z kolei M. Żywczyński pisze o 70 tys. duchownych świeckich oraz 60 tys. zakonników i zakonnic [Żywczyński 1951, 7]. Przytoczone liczby, jak zauważa J.A. Machlejd, bardzo się różnią między sobą. Wg Taine’a i de la Gorce liczba arcybiskupów i biskupów (łącznie z 5 biskupami Korsyki, a pomijając 4 biskupów z Comtat Venaissin i Betleemu) wynosiła 135. Co do kanoników kapituł liczba waha się pomiędzy 500-600. Taine podaje poza tym, w przeciwieństwie do de la Gorce'a, liczbę wikariuszy diecezjalnych oraz opatów wraz z przeorami. W przypadku tych pierwszych liczba ich sięga 2700, a drugich 1500. Kanoników kolegiat Taine szacuje na 5600 . Proboszczów i wikariuszów (w 1789 r. było na terenie Francji 34 tys. 658 parafii) wg Taine'a było 60 tys., zaś wg de la Gorce -50 tys. Ten pierwszy autor oszacował poza tym liczbę zakonników w 2,5 tys. zakonów na 23 tys., a zakonnic w 1.500 zakonów na 37 tys., natomiast w ocenie de la Gorce, zakonników było 25 tys., a zakonnic 35 tys. Ogółem liczba duchowieństwa wg Taine’a wynosiła 130 tys., zaś w ocenie de la Gorce 125 tys. Jak widać dane obu autorów są dość zgodne. Ogółem ludzie stanu duchownego stanowili $0,47 \%$ ogółu ludności, a 0,49\% ogółu ludności katolickiej. Dla porównania przytoczyć można, że w Polsce w tymże czasie, według Korzona, na 4,5 miliona ludności rzymskokatolickiej mogło być około 10 tys. osób duchownych, co stanowiło 0,21\% ludności [Machlejd 1934, 36]. 
włości jego obejmowały 14 mil (lieues) kwadratowych zamieszkiwanych przez 25 tys. mieszkańców. Dochód roczny wynosił 800 tys. franków, co na owe czasy było sumą olbrzymią. Ogólną wartość dóbr nieruchomych francuskiego duchowieństwa szacował Taine na 4 miliardy ówczesnych franków, a dochód - na 80-100 milionów rocznie, do czego należy dodać 123 miliony tytułem dziesięciny, ogółem ponad 200 milionów rocznej renty [Machlejd 1934, 37].

„Ludzi podróżujących po Francji w przeddzień 1789 r. uderzała ogromna potęga Kościoła katolickiego w tym kraju” [Żywczyński 1951, 7]. Z kolei „Biskupi nie czynili przy tym niczego, by zaradzić nędzy, bezradności i niedouczeniu księży parafialnych; więcej nawet - i to jest właśnie kwestia zasadnicza - do faktu, że cały niemal wielomilionowy naród (z nielicznymi wyjątkami) właściwie dokonał apostazji, francuscy purpuraci podchodzili równie emocjonalnie, jak - powiedzmy - nasi zawodowi politycy do faktu, że klasy ubogie nie mają co jeść. Było to dla nich zupełnie normalne" [Belloc 1911, 227] ${ }^{14}$.

Podobnie, jak wśród świeckiej ludności Francji z czasów przedrewolucyjnych, widzimy więc wielką arystokrację u góry, a bardzo liczne ubogie masy u dołu, tak i wśród duchowieństwa zaszczyty i wielkie fortuny przypadają kilkuset prałatom, dostatek panuje wśród kilkunastu tysięcy duchowieństwa wyższego, natomiast olbrzymia, przeszło stutysięczna, masa duchowieństwa francuskiego żyje w niedostatku, czasem nawet w nędzy [Blos 1909, 3-4; Kautsky 1905, 27-28; Żywczyński 1951, 19-21]. Nie było więc zaskoczeniem, że już kiedy 5 maja 1789 r., kiedy zebrały się Stany Generalne [Markow i Soboul 1984, 73-87; Konarski 2012, 239], większość księży solidaryzowała się ze stanem trzecim [Rogier, Bertier de Sauvigny, i Hajjar 1987, 106], gdy w czerwcu 1789 r. debatowano we Francji nad połączeniem stanów, wówczas - wbrew woli biskupów i wyższego duchowieństwa - wiejscy proboszcze przeforsowali uchwałę zjednoczenia się z Izbą Gmin większością 133 głosów, przeciw 114 [Kautsky 1905, 29; Machlejd 1934, 37-38].

${ }^{14}$ Por. Banaszak 1991, 27-28. Z kolei A. Szelągowski i B. Kumor podkreślają, że wielu francuskich duchownych było członkami lóż masońskich [Szelągowski 1927, 155; Kumor 1985, 185]. 


\section{PIERWSZE REFORMY}

Nie podlega dyskusji fakt, iż celem reform organizacji kościelnej w państwie, jakich podjęło się Zgromadzenie Narodowe, stanowiło „przekształcenie Kościoła we Francji zgodnie z poglądami absolutyzmu już oświeconego na prawa państwa w stosunku do Kościoła”, co dokonać się miało za sprawą przeniesienia kompetencji, „które Kościół u monarchów absolutystycznych tolerował, na nowego suwerena - naród" [Grzybowski i Sobolewska 1971, 21]. Tak więc francuski ustawodawca nie wchodząc w sprawy wiary i dogmatów, uznał - zgodnie z myślą polityczną epoki - za należące do kompetencji reprezentacji suwerena, narodu - prawo uregulowania zewnętrznych form działania Kościoła" [tamże, 21] ${ }^{15}$.

Pierwsze reformy stosunków wyznaniowych o charakterze majątkowym miały miejsce już podczas obrad Zgromadzenia Narodowego związanych ze sprawą zrzeczenia się przywilejów feudalnych. 4 sierpnia 1789 r. Zgromadzenie Narodowe ogłosiło zniesienie poddaństwa (servage) feudalnego chłopów, sądownictwa senioralnego i przywilejów z nim związanych, usług osobistych na rzecz dziedziców oraz praw dziedziców do polowania na gruntach chłopskich $^{16}$. Pierwsze zdanie dekretu brzmiało: „Zgromadzenie Narodowe znosi całkowicie ustrój feudalny". Tak więc deputowani postanowili zrezygnować z przywilejów, natomiast biskupi zrezygnowali $\mathrm{z}$ feudalnych należności, zaś proboszczowie ze zwyczajowych opłat wnoszonych przez parafian [Barruel 1815, 31]. Dodatkowo zniesiono annaty, a więc opłaty składane do Rzymu przez mianowanych biskupów.

Dnia 20 sierpnia Zgromadzenie Narodowe wyłoniło ze swojego grona komitet do spraw kościelnych, który miał za zadanie przygotować projekty aktów normatywnych związanych z reformami organizacji kościelnej w państwie $^{17}$. Rola tego komitetu, złożonego zarówno z duchownych, jak i osób świeckich, w dalszych pracach nad reformami kościelnymi będzie miała charakter decydujący o ich kształcie [Pelczar 1922, 13-14].

15 Por. Szelągowski 1934, 240-41, 244-45.

${ }_{16}$ Zob. Arrêté du 4 aout 1789 portant renonciation aux privilèges, w: Archives Parlementaires de 1787 à 1860 - Première série (1787-1799) sous la direction de Jérôme Mavidal et Emile Laurent. Tome VIII du 5 mai 1789 au 15 septembre 1789, Paris 1875, s. 350 [dalej cyt.: AP].

17 Zob. Liste des membres du comité des affaires ecclésiastiques et du comité de judicature, lors de la séance du 20 aout 1789, w: AP, t. VIII, s. 461. 
Kilka dni później, uchwalono Deklarację Praw Człowieka i Obywatela będącą pierwszym aktem konstytucyjnym Francji [Konarski 2017a, 98], w której odniesiono się również do spraw wyznaniowych. O użyteczności religii stanowiły art. 16 i $17^{18}$, zaś - budzący niepokój wśród duchowieństwa art. 10 mówił: „Nikt nie może być prześladowany za swe przekonania, nawet religijne, jeśli manifestowanie ich nie zakłóca ustalonego porządku publicznego" ${ }^{19}$. Niepokój ów wywoływał dodatkowo brak w Preambule Deklaracji postanowień wskazujących na dominującą rolę Kościoła rzymskokatolickiego.

Następnym posunięciem władz francuskich w zakresie spraw organizacji kościelnej było oficjalne zniesienie tego „feudalnego barbarzyństwa” jak określano w kajetach skarg (cahiers de doleances) dziesięciny - $\mathrm{w}$ dniu 28 września $1789 \mathrm{r}^{20}$, chociaż $\mathrm{w}$ praktyce pobierano ją $\mathrm{w}$ dalszym ciągu, oczekując na ustanowienie nowego rodzaju opłat, które zapewniłyby duchowieństwu wpływy [Duby i Mandrou 1965, 429]. Dziesięcina w pierwszym okresie istnienia kościoła chrześcijańskiego stanowiła dobrowolną daninę wiernych na rzecz kapłanów i dopiero w VIII w. została zamieniona przez Karola Wielkiego na obowiązek powszechny ${ }^{21}$. Dochody francuskiego duchowieństwa wynikające $\mathrm{z}$ dziesięciny wynosiły rocznie około 180 do 200 milionów liwrów [Żywczyński 1951, 8; Banaszak 1991, 26-27], natomiast L. Mezzadri oblicza tę kwotę na 80 milionów liwrów [Mezzadri 2007, 65].

Jedną z najbardziej doniosłych w skutkach decyzji francuskiej władzy ustawodawczej dla pozycji Kościoła było uchwalenie 2 listopada 1789 r. przez Konstytuantę zdecydowaną większością głosów (568 za, 340 przeciw)

${ }^{18}$ Dyskusję nad deklaracją praw rozpoczęto 20 sierpnia i w kolejnych dniach - do 26 sierpnia - przyjmowano kolejne jej postanowienia. Wymienione artykuły 14-17 przyjęto w dniu 26 sierpnia.

19 Artykuł ten przyjęto w dniu 23 sierpnia, zob. Adoption de l'article 10 de la déclaration des droits, lors de la séance du 23 aout 1789, w: AP, t. VIII, s. 480.

${ }^{20}$ Zob. Décret du 28 septembre 1789 sur l'abolition des droits de franc-fief, w: AP, t. IX, s. 199-200.

${ }^{21}$ Dziesięcina swoje źródło posiada w Piśmie Starego Testamentu, zob. m.in.: Rdz 47,15-16; Rdz 47,19; Rdz 47,22; Rdz 47,23-24; Pwt 14,22-27; Pwt 14,28-29; 2 Krn 17,5. Szerzej na temat tego rodzaju daniny w Polsce, zob. Dudziak, 1974; Kowalska 1956, 71101; Wajs 1986, 68-88; Leskiewicz i Michalski 1954, 199, 279-80. Echa powinności składania daniny Kościołowi w postaci dziesięciny przeniknęły również do literatury pięknej wyrażającej się w sposób dosadnie negatywny o tej powinności chłopskiej, zob. Potocki 1907, 277. W Królestwie Polskim dziesięcinę zniesiono dopiero na mocy art. 27 ukazu carskiego z 14 (26 grudnia) 1865 r. [Jemielity 1997, 239-62]. 
dekretu o sekularyzacji majątków kościelnych ${ }^{22}$, które miały posłużyć - jak zaznaczył biskup Charles-Maurice de Talleyrand-Périgord - do spłaty długów państwowych, ocenianych na 3 miliardy liwrów. Kwestia nacjonalizacji majątków kościelnych dyskutowana była już przed Rewolucją, a więc jej przegłosowanie było tylko sprawą czasu ${ }^{23}$. Dobra kościelne stały się tym samym własnością narodu (suwerena) [Grzybowski i Sobolewska 1971, 21], zaś państwo zobowiązało się pokrywać wydatki związane z kultem religijnym oraz łożyć na utrzymanie księży i opiekę nad ubogimi. Za utracone beneficjum biskupi mieli otrzymać od 12 do 50 tys. liwrów rocznego dochodu, zaś proboszczom przyznano co najmniej 1200 liwrów rocznej rekompensaty, co oznaczało, że sytuacja materialna niektórych duchownych uległa znacznej poprawie, innych natomiast - pogorszeniu [Rogier, Bertier de Sauvigny, i Hajjar 1987, 107]. Konstytuanta dokonując sekularyzacji majątków kościelnych nie kierowała się jakąkolwiek wrogością do Kościoła i katolicyzmu, jak postrzegają to często przeciwnicy reformy. Deputowani będąc reprezentantami suwerennego narodu uznali się po prostu za powołanych do regulowania organizacji kościelnej w takim samym stopniu, w jakim przedtem rościła sobie do tego pretensje władza królewska. Niemniej do czasu sprzedaży dóbr duchowieństwa wyemitowano tzw. asygnaty, stanowiące tytuły kredytowe, których gwarancją miały być - obok właśnie dóbr kościelnych - również dobra koronne i majątki emigrantów [Bainville 1946, 300], co spowodowane było pilną potrzebą zasilenia gotówką kasy państwowej [Mezzadri 2007, 67; Barruel 1815, 39-41].

Kolejne reformy spraw wyznaniowych miały miejsce 13 lutego 1790 r., kiedy to zniesione zostały zakony i klasztory, z wyjątkiem tych, które prowadziły szpitale i szkoły ${ }^{24}$. Decyzję o likwidacji argumentowano opierając się myśli oświeceniowej, zgodnie $\mathrm{z}$ którą nowoczesny człowiek powinien angażować się w działalność produktywną i być pożytecznym dla świata, zaś zakony kontemplacyjne uznawano powszechnie - nie tylko zresztą przez „rewolucjonistów”, ale i przez znaczną część duchowieństwa - po prostu za ostoję próżności, nieprowadzące żadnej użytecznej działalności [Barruel

${ }^{22}$ Zob. Décret du 2 novembre 1789 sur les biens ecclésiastiques, w: AP, t. IX, s. 649.

23 „Sądzono, że odebranie tych dóbr - to odsunięcie szlachty od rządów w Kościele, to ułatwienie dojścia do stanowisk biskupich i opackich ludziom o pochodzeniu plebejskim" [Żywczyński 1951, 38].

${ }^{24}$ Zob. Décret concernant le sort des religieux et des maisons hospitalières et d'éducation publique, sur proposition de M. Le Chapelier, lors de la séance du 13 février 1790, w: AP, t. IX, s. 592 [Sagnac 1921, 187]. 
1815, 47-48; Kumor 1985, 187-88; Burleigh 2011, 67-68; Carroll 2011, 15960]. Likwidacja tych zakonów oznaczała jednocześnie zwolnienie ze ślubów zakonników i zakonnic - stanowiących zaledwie 3\% ogółu duchowieństwa we Francji, którym przyznano dożywotnią rentę, ale pod warunkiem opuszczenia na stałe zgromadzenia ${ }^{25}$. W sytuacji, w której wspomniani nie chcieli opuścić swoich zgromadzeń, grupowano ich w zredukowanej liczbie domów zakonnych [Rogier, Bertier de Sauvigny, i Hajjar 1987, 108]. Wielu $\mathrm{z}$ tych duchownych po jakimś czasie jednak rezygnowała z życia monastycznego i zrzucało habit, często odnajdując później swoje powołanie w szeregach najbardziej aktywnych rewolucjonistów. Byli jednak i tacy, którzy po opuszczeniu swoich zgromadzeń żyli w nędzy ${ }^{26}$. Zresztą nieuprawnione jest

${ }^{25}$ Decyzję w sprawie uposażeń duchowieństwa zakonnego podjęto w dniu 17 lutego, zob. Décret sur l'ordre du travail et du traitement à accorder aux religieux et aux religieuses, lors de la séance du 17 février 1790, w: AP, t. XI, s. 623-24. Z kolei dzień później - 18 lutego, postanowiono o uposażeniach zakonników, zob. Décret sur le traitement à faire aux religieux, lors de la séance du 18 février 1790 au matin, w: AP, t. XI, s. 641. Na temat przebiegu dyskusji w komisji kościelnej z dnia następnego, zob. Ordre du jour de la séance du 19 février 1790: discussion sur le projet de décret du comité ecclésiastique relatif aux ordres religieux, w: AP, t. XI, s. 646. Wysokość pensji zakonników ustalono 20 lutego stanowiąc, że zakonnicy, którzy nie złożyli ślubów, będą otrzymywali 300, 400 i 500 liwrów rocznie, zaś zakonnicy utrzymujący się z jałmużny 700, 800 i 900 liwrów, natomiast członkowie zakonów kontemplacyjnych i byli jezuici 900, 1000 i 1200 liwrów, zob. Projet de décret du comité ecclésiastique sur l'incapacité des religieux à succéder et à recevoir des libéralités, lors de la séance du 20 février 1790 au matin, w: AP, t. XI, s. 651; Discussion du projet de décret du comité ecclésiastique sur l'incapacité des religieux à succéder et à recevoir des libéralités, lors de la séance du 20 février 1790 au matin, w: tamże, s. 651-52; Adoption du projet de décret du comité ecclésiastique sur l'incapacité des religieux à succéder et nouvelle rédaction par le comité, lors de la séance du 20 février 1790 au matin, w: tamże, s. 652. Kolejne dekrety w sprawach duchowieństwa zakonnego wydano 19 marca, zob. Adoption de l'article 1,2,3 du projet de décret concernant les religieux des différents ordres du royaume, lors de la séance du 19 mars 1790, w: AP, t. XII, s. 238-41. Dnia 20 marca uchwalono dekret o domach zakonnych, zob. Décret du 20 mars 1790 sur les maisons religieuses, w: tamże, s. 267. W kolejnych miesiącach uchwalono dekrety regulujące wysokość wynagrodzenia zakonnic (21 września i 2 października). Wydarzenia we Francji - również te związane ze sprawami wyznaniowymi - były szeroko komentowane na łamach ówczesnej prasy polskiej, w szczególności przez „Gazetę Warszawską” [Karkocha 2011, 142-61].

${ }^{26} \mathrm{~W}$ obronę tych byłych zakonników brał deputowany M. Robespierre, który dla tych mnichów, którzy znaleźli się bez środków do życia, domagał się „względnego, a nawet wspaniałomyślnego traktowania”, zaś o całym niższym duchowieństwie Robespierre mówił, że „zestarzał się w służbie i po pracy całego życia nic nie miał oprócz schorzeń i słabości. Wymaga on szczególnej uwagi nie tylko jako kler, ale bardziej jeszcze jako biedota" [Thompson 1937a, 164-65]. 
twierdzenie, że większość duchownych wyrażała oburzenie z powodu dotychczasowych decyzji Zgromadzenia Narodowego [Żywczyński 1951, 38-39]. „Przeciwnie, księża mogli równie dobrze potraktować je jako wyraz tendencji do powrotu do apostolskiej prostoty z czasów wczesnego Kościoła, a także zbawiennego $\mathrm{w}$ swej istocie wyrzeczenia się dóbr materialnych stanowiących potencjalne źródło demoralizujących pokus i zepsucia”, zaś „Optymiści zawsze mogli powiedzieć, że Zgromadzenie Narodowe wykonuje po prostu pracę reformatorskiego soboru kościelnego. Byli także i tacy duchowni, którzy podążając tą drogą rozumowania, dochodzili do logicznego wniosku, iż w kraju należy wprowadzić coś na kształt religii narodowej mającej za podstawę unię egalitarystycznego Kościoła narodowego ze zdemokratyzowanym państwem. Dzięki Rewolucji wielkie prawdy religijne znajdowały możliwość społecznego wyrazu" [Burleigh 2011, 68]. Koncepcje religii narodowej zostaną zrealizowane już w późniejszym okresie rządów - trzeciego z kolei rewolucyjnego ciała prawodawczego Francji - Konwencji [Dmochowski 2016, 308-26], a w szczególności w okresie sprawowania władzy przez stronnictwo jakobińskie ${ }^{27}$, po wyeliminowaniu Żyrondy ze sceny politycznej ${ }^{28}$.

\section{KONSTYTUCJA CYWILNA DUCHOWIEŃSTWA}

W analizowanym okresie, niejako kwintesencją dotychczasowych reform organizacji kościelnej we Francji [Szelągowski 1934, 248-49], stała się uchwalona „przeważnie za sprawą jansenistów Treilharda i Camusa” [Pelczar 1922, 15; Barruel 1815, 55; Duby i Mandrou 1965, 329-34; Carroll 2011, 153-55] - po dwóch miesiącach dyskusji w piętnastoosobowym Komi-

${ }^{27} \mathrm{Na}$ temat religijnej koncepcji Robespierre'a zob. Baszkiewicz 1989, 268-70; Hardman 1999, 140; Scurr 2008, 262-64; Israel 2014, 561; por. mowę Robespierre’a o „stosunkach idei religijnych i moralnych do zasad republikańskich”, która została wygłoszona w Konwencie 7 maja 1794 r. [Thompson 1937b, 216-21]. Pełne tłumaczenie tej mowy w j. angielskim zob. Beik 1970, 299-312. Na czele z Robespierre'em jakobinom gotowego zespołu formuł teoretycznych i ideologicznych, ale również zespołu formuł estetycznych i religijnych, dostarczyły dzieła J.J. Rousseau, w szczególności Księga IV, Rozdział VIII jego „Umowy społecznej” [Baczko 2009, 395; Rousseau 1920, 112-22; Seidler 1984, 91; Furet i Ozouf 1989, 309].

${ }^{28}$ Rozruchy, które poprzedziły aresztowanie deputowanych Żyrondy w dniu 2 czerwca 1793 r., „były prawdziwym zamachem stanu paryskich władz miejskich przeciwko przedstawicielstwu departamentów, a pierwszym jego skutkiem było powstanie prowincji przeciwko stolicy" [Gaxotte 2010, 251]; por. Konarski 2017b, 44-48. 
tecie Kościelnym złożonym z dwóch biskupów, dwóch proboszczów i dziesięciu świeckich - w dniu 12 lipca 1790 r. Konstytucja cywilna duchowieństwa (Constitution civile du Cle rgé) [Misermont 1917, 33-36], która stanie się prawdziwym zalążkiem wieloletniego konfliktu w relacjach państwo-Kościół w rewolucyjnej Francji [Gazier 1887, 12; Kumor 1985, 188].

Ten akt normatywny swoje źródło posiadał w tradycji gallikańskiej [Sciout 1872-1881, 53-61]. Od wieków państwo miało we Francji ogromny wpływ na kościelne struktury i kadry, co oznaczało, że twórcy konstytucji cywilnej nie dopuszczali nawet myśli, że popełniają jakieś świętokradztwo [Baszkiewicz 1993, 281], bowiem deputowani uznali, że dawne kompetencje królewskie w tym zakresie przysługują teraz przedstawicielom suwerennego narodu [Sciout 1872-1881, 180-261]. Po zniesieniu dziesięcin i nacjonalizacji dóbr kościelnych niezbędne stało się trwałe uregulowanie zasad finansowania Kościoła katolickiego z budżetu państwa. „Cywilna konstytucja kleru obalała hierarchiczny ustrój Kościoła we Francji, odrywała go od ogniska jedności, od Rzymu i tamowała wykonywanie jurysdykcji duchownej, poddając natomiast biskupów i kapłanów nieograniczonej władzy państwa" [Pelczar 1922, 16].

Zgodnie z dyspozycją Konstytucji duchowni wszystkich szczebli mieli otrzymywać wynagrodzenie od państwa w zależności od wielkości parafii i piastowanego stanowiska ${ }^{29}$. Wynagrodzenie miało być wypłacane $\mathrm{z}$ góry co trzy miesiące przez skarbnika okręgu (dystryktu), przy czym wobec otrzymywania wynagrodzenia ze skarbu państwa, wszelkie posługi (funkcje) świadczone przez nich dla ludności miały stać się bezpłatne.

Wynagrodzenie biskupów zostało uregulowane w następujący sposób: arcybiskup Paryża miał otrzymywać 75 tys. liwrów, zaś biskupi w miastach liczących ponad 50 tys. mieszkańców -20 tys. liwrów, pozostali zaś -12 tys. liwrów. Z kolei wynagrodzenie wikariuszy przy kościołach katedralnych

\footnotetext{
${ }^{29}$ Już w trakcie głównej debaty nad konstytucją cywilną duchowieństwa w dniu 31 maja, Robespierre mówił: „Księża, jako członkowie społeczeństwa są po prostu urzędnikami, których obowiązkiem jest publiczne wykonywanie i utwierdzanie wiary” [Thompson 1937a, 162]. Dla Robespierre'a „wszystkie zbędne urzędy kościelne, jak arcybiskupstwa i godności kardynalskie, powinny być zniesione, a zachować należy jedynie te, które potrzebne są społeczeństwu; (...) urzędnicy duchowni, podobnie jak wszyscy urzędnicy, powinni być obierani drogą wyborów powszechnych; (...) powinni być wynagradzani podobnie jak urzędnicy cywilni” [tamże, 162-63]. Biograf Robespierre'a podkreśla, że ten otrzymywał wiele listów (pisanych po łacinie, po grecku, po hebrajsku) ze wszystkich stron kraju - z wyrazami uznania, bowiem był on niewątpliwie wyrazicielem uczuć dużej części duchowieństwa [tamże, 164].
} 
kształtowało się w sposób następujący: dla pierwszego wikarego 6 tys. liwrów, dla drugiego 4 tys. liwrów, dla pozostałych - po 3 tys. liwrów. W miastach powyżej 50 tys. mieszkańców dla pierwszego wikarego przewidziano 4 tys. liwrów, zaś dla pozostałych po 3 tys. liwrów. Natomiast w miastach poniżej 50 tys. mieszkańców, wynagrodzenie pierwszego wikarego wynosić miało 3 tys. liwrów, drugiego -2 tys. 400 liwrów, zaś dla pozostałych po 2 tys. liwrów.

W przypadku wynagrodzenia plebanów zastosowano następujące rozwiązanie: w Paryżu każdy pleban miał otrzymywać 6 tys. liwrów, zaś w miastach powyżej 50 tys. mieszkańców, wynagrodzenie to miało wynosić 4 tys. liwrów. W miastach liczących od 10 do 50 tys. mieszkańców wynagrodzenie plebanów ustalono na 3 tys. liwrów. Z kolei w miastach liczących 3 tys. mieszkańców plebani mieli otrzymywać 2 tys. liwrów, zaś na wsiach liczących powyżej 2 tys. mieszkańców - po 1800 liwrów, wsiach liczących od 1 do 2 tys. mieszkańców - 1500 liwrów, natomiast w parafiach liczących do 1 tys. mieszkańców, wynagrodzenie ustalono na 1 tys. liwrów. Co zaś do wynagrodzenia wikariuszy parafialnych, ustalono, że w Paryżu pierwszy wikariusz otrzymywać będzie 2 tys. 400 liwrów, drugi - 1500 liwrów, zaś pozostali po 1 tys. liwrów. We wszystkich miastach i miasteczkach ustalono wynagrodzenie po 800 liwrów dla pierwszych i, po 700 liwrów dla pozostałych, podobnie zresztą jak kwota wynagrodzenia wikarych we wszystkich parafiach wiejskich.

Potrzeba reform struktur kościelnych (diecezji, parafii) była odczuwana przez duchowieństwo już przed Rewolucją. Konstytucja cywilna dopasowała struktury kościelne do nowego podziału administracyjnego państwa i powierzyła obsadzanie funkcji biskupów oraz proboszczów wyborom - na ogólnych zasadach wybierania funkcjonariuszy publicznych. Francja została podzielona na 83 departamenty, co oznaczało konieczność dopasowania granic istniejących parafii do granic departamentów. Od tej chwili każda parafia miała liczyć 6 tys. wiernych, zaś o modyfikacjach granic już istniejących parafii lub o powstaniu nowych miały decydować okręgowe zgromadzenia administracyjne działające w porozumieniu z biskupami. Skutkiem tej reformy była likwidacja około 4 tys. parafii. Jednocześnie wprowadzono nową hierarchię stanowisk kościelnych (arcybiskup - biskup metropolita; biskup; wikariusz katedralny; wikariusz przełożony seminarium w każdej diecezji miało znajdować się seminarium duchowne; wikariusz dyrektor seminarium; proboszcz i wikariusz probostwa), likwidując przy 
tym pozostałe urzędy kościelne, takie jak: kapelanie, prebendy, opactwa, przeorstwa, kanonie.

W odniesieniu do zasad wyboru biskupów i proboszczów, to konstytucja cywilna przewidywała ich wybór przez zgromadzenia elekcyjne w poszczególnych departamentach i okręgach, przy czym głosowanie miało posiadać charakter tajny, zaś o wyborze decydować miała większość głosów. O godność biskupa mogła ubiegać się osoba, która przez co najmniej 10 lat w danej diecezji pełniła urząd plebana, albo przez 15 lat pełniła urząd wikariusza w kościele katedralnym lub seminarium duchownym. W przypadku osób ubiegających się o urząd proboszcza, należało wykazać się co najmniej 5-letnią posługą duszpasterską w kościele parafialnym albo w szpitalu, przy czym w przypadku proboszczów, których parafie zostały zlikwidowane, nie musieli wykazywać się tym okresem. Objęcie urzędu było jednak, zarówno w przypadku biskupów, jak i proboszczów, obwarowane obowiązkiem złożenia przysięgi, w której zobowiązywał się troszczyć o parafian, dochować wierności narodowi, prawu i królowi oraz wspierać realizację konstytucji.

Konstytucja nakładała na biskupów obowiązek rezydowania, zgodnie z którym żaden biskup nie mógł oddalić się ze swej diecezji na czas dłuższy niż 15 dni w ciągu roku z wyjątkiem „ostatniej potrzeby”, na którą jednak i tak musiał wyrazić zgodę przełożony duchownego (dyrektoriat okręgowy w przypadku biskupa, biskup w przypadku proboszcza, proboszcz w przypadku wikarego). Sankcją za złamanie tych postanowień było upomnienie, zaś w przypadku powtórzenia się czynu - utrata wynagrodzenia za czas absencji.

Postanowienia konstytucji cywilnej duchowieństwa do 5 listopada $1790 \mathrm{r}$. pozostawały w zawieszeniu [Szelągowski 1934, 256-57], i dopiero tego dnia podjęto w Zgromadzeniu Narodowym dyskusję na temat, w jaki sposób zrealizować postanowienia konstytucji. Fakt, że pierwsze protesty biskupów zaczęły się pojawiać nieśpiesznie - dopiero we wrześniu - o najważniejszej zasadzie konstytucji zaś, przysiędze obywatelskiej, którą księża mieli obowiązek składać, do końca roku, nawet nie debatowano [Belloc 1911, 240].

W dniu 27 listopada uchwalono dekret, według którego wszyscy księża mieli złożyć przysięgę na wierność konstytucji [Sciout 1872-1881, 398-433], co spotkało się ze znacznym oporem wśród duchowieństwa, skutkiem czego doszło do rozłamu [Sagnac 1906, 97-115; Latreille, Palanque, Delaruelle, i Rémond 1962, 87-90], zaś król zatwierdził ten dekret w dniu 26 grudnia 
[Sciout 1872-1881, 262-94; Belloc 1911, 240]. Od tego momentu duchowni mieli osiem dni na złożenie przysięgi. Duchowni, którzy odmówili złożenia przysięgi, musieli liczyć się z koniecznością rezygnacji z piastowanych urzędów [Burleigh 2011, 72; Banaszak 1991, 32], mimo że kilka miesięcy później - 11 kwietnia - opublikowano dekret zezwalający kapłanom niezaprzysiężonym na wykonywanie praktyk religijnych, traktując ich jak duchownych wyznania tolerowanego. Do dnia 4 stycznia $1791 \mathrm{r}$. [Misermont 1917, 14-16, 100-101] złożyło przysięgę tylko 105 deputowanych duchownych [Szelągowski 1934, 259]. Niemal wszyscy biskupi i 2/3 proboszczów - do tej pory oddani Rewolucji i gotowi zaakceptować konstytucję cywilną - odmówili złożenia przysięgi [Burleigh 2011, 73]. Na niedzielę 9 stycznia 1791 r. zaplanowano uroczyste złożenie przysięgi przez duchownych, jednakże biskupi odmówili złożenia przysięgi (poza czterema z nich Talleyrand, Lomenie de Brienne, Jarente i Lafont de Savine) [Markov i Soboul 1984, 141]. Tylko niewielka część duchownych przysięgała tego dnia, po czym jednak część z nich wycofała się ze złożonej przysięgi, gdy papież Pius VI opublikował 13 kwietnia kolejne - po wydanym 10 marca breve Quod aliquantum (potępiającym konstytucję cywilną i uznającym ją za nieważną $)^{30}$ - breve Charitas quae (o przysiędze cywilnej duchowieństwa) ${ }^{31}$.

Reformy organizacji Kościoła rzymskokatolickiego we Francji, będące próbą jego etatyzacji, doprowadziły tym samym do jego wewnętrznego rozłamu [Carroll 2011, 157-58], którego przejawem była emigracja duchownych niezaprzysiężonych i prześladowania pozostałych w kraju [Kumor

${ }^{30}$ Tekst breve w j. włoskim zob. http://w2.vatican.va/content/pius-vi/it/documents/ breve-quod-aliquantum-10-marzo-1791.html [dostęp: 27.11.2018].

${ }^{31}$ Tekst breve w j. włoskim zob. http://w2.vatican.va/content/pius-vi/it/documents/ breve-charitas-quae-13-aprile-1791.html [dostęp: 27.11.2018]. Papież pisze: „błagamy was wszystkich, umiłowane katolickie dzieci w królestwie Francji: jak przyjęliście religię i wiarę waszych ojców, zalecamy wam z miłością nie porzucać jej. Ponieważ istnieje tylko jedna prawdziwa religia, która daje zarówno życie wieczne, jak i czyni bezpiecznym i prosperującym społeczeństwo świeckie. Uważnie strzeżcie się użyczania swych uszu dla zdradzieckiej mowy - filozofii tego wieku, która prowadzi do śmierci. Trzymajcie się z dala od wszelkich intruzów, nazywających siebie arcybiskupami, biskupami lub proboszczami. Nie utrzymujcie z nimi wspólnoty, szczególnie w zakresie czci Bożej. Słuchajcie pilnie wiadomości waszych prawowitych pasterzy, którzy cały czas żyją, i którzy będą odpowiedzialni za was później, zgodnie z kanonami. W końcu jednym słowem: bądźcie blisko Nas. Bo nikt nie może być w Kościele Chrystusa, nie będąc w jedności z Jego widzialną głową i założoną przez Niego Stolicą św. Piotra. Aby zachęcić wszystkich do bardziej żarliwego spełniania swych powinności, błagamy niebiańskiego Ojca, żeby zesłał wam Ducha rady, prawdy i stałości”. 
1985, 189; Carroll 2011, 177-201], postępujący w stronę dechrystianizacji ruch rewolucyjny, który dodatkowo napędzany był przez reakcję kontrrewolucyjną, która wykorzystała zatarg państwa z Kościołem, jako sposób na przyciągnięcie do swoich szeregów duchownych niezaprzysiężonych, a wraz z nimi mas ludności, głównie na prowincji [Latreille, Palanque, Delaruelle, i Rémond 1962, 114].

\section{ZAKOŃCZENIE}

W pierwszych latach przewrotu społeczno-politycznego określanego Rewolucją francuską, w zakresie spraw organizacji kościelnej i spraw stricte wyznaniowych, wyróżnić należy dwa okresy: okres etatyzacji Kościoła we Francji i okres dechrystianizacji [Plongeron 1969, 101-77; Markov i Soboul 1984, 271-76]. Pierwszy z tych okresów, który był liczny w reformy Zgromadzenia Narodowego odnoszące się do struktury organizacyjnej, środków finansowania i spraw osobowych, przypada na okres od maja 1789 r. do października 1793 r. Jest to okres, w którym nie mamy jeszcze do czynienia z aktami jawnej agresji wobec Kościoła, którego schyłek możemy upatrywać w kryzysie religijnym będącym skutkiem obowiązku składania przysięgi na wierność konstytucji przez ogół księży i potępieniem przez papieża Piusa VI konstytucji cywilnej w breve Quod aliquantum z 1791 r. oraz późniejszą reakcją duchowieństwa francuskiego na przeprowadzone reformy, będącą tym bardziej słuszną, że przecież uchwalając ustawę cywilną Konstytuanta przekroczyła swoje uprawnienia prawotwórcze, zaś sama ustawa stawała w sprzeczności z konkordatem z 1516 r. Z kolei drugi okres - okres jawnej dechrystianizacji - wiązał się z postępującą laicyzacją państwa, która swój wyraz miała m.in. we wprowadzeniu kalendarza republikańskiego, zmianą nazw miejscowych odwołujących się do religii, konfiskatą kosztowności kościelnych i dzwonów (mimo że na cele obrony narodowej), a także masowym zamykaniem kościołów, wyburzaniem ich, a przede wszystkim wymuszaniem na konstytucyjnych księżach zupełnego zrzeczenia się kapłaństwa i skłaniania ich do zawierania małżeństw [Kumor 1985, 189-91; Banaszak 1991, 36-37]. Poza tym - w dalszym ciągu wprowadzenie kultu Rozumu i następnie jego przeciwwagi - kultu Istoty Najwyższej [Baszkiewicz 1989b, 234]. Podział ten (okres etatyzacji i okres 
dechrystianizacji) ma wyłącznie charakter obrazowy. Oznacza to na przykład, że w pierwszym okresie - etatyzacji Kościoła - zauważyć można już od 1791 r., kiedy to dotychczasowy „katolicko-rewolucyjny synkretyzm świąt od tej pory zanika" [Tenże 1993, 284], że mimo to jeszcze przez jakiś czas msze podczas świąt patriotycznych będą miały miejsce we Francji.

Dokonana analiza procesu etatyzacji Kościoła rzymskokatolickiego we Francji, jaki miał miejsce we Francji w latach 1789-1790 prowadzi do następującej konkluzji, iż mimo że organizacja kościelna we Francji uległa znacznym przemianom $\mathrm{w}$ duchu programu rewolucji narodowej, zaś postępująca laicyzacja dodatkowo nie sprzyjała religijności, to jednak wielu duchownych poparło reformy parlamentarne w zakresie zmiany stosunków państwo-Kościół. Entuzjazm dla tych reform pochodził przede wszystkim z niższych warstw duchowieństwa, które skorzystało materialnie na zmianach, mimo że pozycja Kościoła we Francji została podważona, czego skutkiem były liczne konfiskaty dóbr kościelnych. Reformy organizacji kościelnej, traktowane przez jej przeciwników nieraz w kategoriach „walki z Kościołem”, nie zawsze są za uznawane za taką „walkę” w kręgach samego duchowieństwa. „Jeśli można mówić o stratach, to nie należy do nich ta najbardziej rzucająca się w oczy, tzn. pauperyzacja Kościoła, ale właśnie bierne przypatrywanie się przechodzącemu lub odchodzącemu obok światu, który przez wieki był punktem odniesienia ewangelizacji, a teraz poszedł własną drogą. Nie usiłowano jej rozpoznać, by wnieść na nią wartości, jakimi Kościół zawsze w dziejach karmił społeczności poddane jego pieczy. Kościół zatem nie uwzględnił w swych rachubach zdobyczy rewolucji francuskiej bądź uczynił to ze zbyt dużym opóźnieniem. Skutki tego są czytelne do dzisiaj” [Zieliński 1993, 61]. Dosadne to stwierdzenie, w ustach kapłana, jeszcze bardziej uzmysławia nam fakt, że dziejów Rewolucji we Francji nie sposób traktować w sposób jednoznaczny i wyłącznie bezwzględnie krytyczny.

\section{PIŚMIENNICTWO}

Baczko, Bronisław. 2009. Rousseau: samotność i wspólnota. Gdańsk: Wydawnictwo „słowo/obraz terytoria”.

Bainville, Jacques. 1946. Dzieje Francji. Tłumaczenie Tadeusz Stryjeński. Warszawa: Wydawnictwo J. Przeworskiego. 
Banaszak, Marian. 1991. Historia Kościoła Katolickiego. T. 3, Czasy nowożytne 1758-1914. Warszawa: Akademia Teologii Katolickiej.

Barruel, Augustin. 1815. Historia duchowieństwa $w$ czasie rewolucji francuskiej. T. I-II. Kraków: [s.n.].

Baszkiewicz, Jan. 1989a. Francuzi 1789-1794. Studium świadomości rewolucyjnej. Warszawa: Książka i Wiedza.

Baszkiewicz, Jan. 1989b. Maksymilian Robespierre. Wrocław: Zakład Narodowy im. Ossolińskich.

Baszkiewicz, Jan. 1993. Nowy człowiek, nowy naród, nowy świat. Mitologia i rzeczywistość rewolucji francuskiej. Warszawa: Państwowy Instytut Wydawniczy.

Baszkiewicz, Jan. 1999. Historia Francji. Wrocław: Zakład Narodowy im. Ossolińskich.

Beik, Paul Harold. 1970. The French Revolution. The Documentary History of Western Civilization. London: Palgrave Macmillan.

Belloc, Hillaire. 1911. The French Revolution. London: Williams \& Norgate.

Blos, Wilhelm. 1909. Rewolucja francuska. Tłumaczenie Bolesław Limanowski. Kraków: Spółka Nakładowa „Książka”.

Burleigh, Michael. 2011. Ziemska władza. Polityka jako religia. Tłumaczenie Jerzy Korpanty. Warszawa: Świat Książki.

Carroll, Warren. 2011. Historia chrześcijaństwa. T. 5. Rewolta przeciw chrześcijaństwu. Tłumaczenie Jan Przybył. Wrocław: Wydawnictwo „Wektory”.

Chłopecki, Jerzy. 1981. Rewolucja i postęp. Warszawa: Państwowy Instytut Wydawniczy.

Desan, Suzanne. 1990. Recaliming the Second. Lay Religion and Popular Politics in Revolutionary France. New York: Cornell University Press.

Dmochowski, Tadeusz. 2016. „Rewolucja francuska wobec Kościoła katolickiego w okresie Konwencji (1792-1795).” Cywilizacja i Polityka 14:308-26.

Duby, Georges, i Robert Mandrou. 1965. Historia kultury francuskiej. Wiek X-XX. Tłumaczenie Hanna Szumańska-Grossowa. Warszawa: Państwowe Wydawnictwo Naukowe.

Dudziak, Jan. 1974. Dziesięcina papieska $w$ Polsce średniowiecznej. Lublin: Towarzystwo Naukowe KUL.

Duguit, Léon, Henry Monnier, and Roger Bonnard. 1952. Les constitutiones et les principales lois politiques de la France depuis 1789. Ed. 7. Paris: R. Pichon \& R. Durand-Auzias.

Faral, Edmond. 1969. Życie codzienne we Francji w czasach Ludwika Świętego. Tłumaczenie Eligia Bąkowska. Warszawa: Państwowy Instytut Wydawniczy.

Furet, François, and Mona Ozouf. 1989. A Critical Dictionary of the French Revolution. Harvard: The Harvard University Press.

Gaxotte, Pierre. 2010. Wielka Rewolucja Francuska. Tłumaczenie Jan Furuhjelm. Komorów: Wydawnictwo „Antyk”.

Gazier, Augustin. 1887. Études sur l'histoire religieuse de la Révolution française d'après les documents originaux et inédits depuis la réunion des États généraux jusqu'au Directoire. Paris: A. Colin.

Grzybowski, Konstanty, i Barbara Sobolewska. 1971. Doktryna polityczna i społeczna papiestwa (1789-1968). Warszawa: Państwowe Wydawnictwo Naukowe.

Hardman, John. 1999. Robespierre. Edinburgh: Longman. 
Hazard, Paul. 1972. Myśl europejska w XVIII wieku. Od Monteskiusza do Lessinga. Tłumaczenie Halina Suwała. Warszawa: Państwowy Instytut Wydawniczy.

Israel, Jonathan. 2014. An Intellectual History of the French Revolution from The Rights of Man to Robespierre. Princeton: Princeton University Press.

Jemielity, Witold. 1997. „Dziesięciny kościelne w Królestwie Polskim.” Prawo Kanoniczne 40, nr 3-4:239-62.

Kaczyńska, Elżbieta, i Kazimierz Piesowicz. 1977. Wykłady z powszechnej historii gospodarczej (od schytku średniowiecza do I wojny światowej). Warszawa: Wydawnictwo Naukowe PWN.

Karkocha, Małgorzata. 2011. Obraz Francji na tamach prasy warszawskiej $z$ lat 1789-1794. Łódź: Wydawnictwo Uniwersytetu Łódzkiego.

Kautsky, Karol. 1905. Przeciwieństwa interesów klasowych roku 1789. Tłumaczenie Antoni Krasnowolski. Warszawa: „Biblioteka Narodowa”.

Konarski, Marcin. 2012. „Zarys ustroju Francji w latach 1789-1794.” Studia Prawnicze i Administracyjne 1:231-54.

Konarski, Marcin. 2016. „Prawo i rewolucja: Rozważania jurysty o rewolucji francuskiej 1789-1794." Studia Prawnicze i Administracyjne 1:31-47.

Konarski, Marcin. 2017a. „Oblicza demokracji totalnej na przykładzie prawodawstwa Wielkiej Rewolucji Francuskiej.” W Bezpieczeństwo-Prawo-Gospodarka, red. Marcin Jurgilewicz, Tadeusz Leszczyński, i Norbert Malec, 89-116. Kraków: Polskie Towarzystwo Geopolityczne.

Konarski, Marcin. 2017b. „Zamach stanu w perspektywie prawno-historycznej na przykładzie Rewolucji Francuskiej 1789-1799.” W Przestępstwa przeciwko bezpieczeństwu i porzadkowi publicznemu, red. Wojciech Lis, 19-64. Lublin: Wydawnictwo KUL.

Kowalska, Halina. 1956. „Walka o dziesięciny na sejmach egzekucyjnych w latach 1562-1565.” W Odrodzenie i Reformacja w Polsce, red. Oskar Bartel i in., t. 1, 71-101. Warszawa: Państwowe Wydawnictwo Naukowe.

Kumor, Bolesław. 1985. Historia Kościoła. Cz. 6, Czasy nowożytne. Kościót w okresie absolutyzmu i Oświecenia. Lublin: Redakcja Wydawnictw KUL.

Latreille, André, Jean-Rémy Palanque, Éienne Delaruelle, and René Rémond. 1962. Histoire du catholicisme en France. Vol. 3, La période contemporaine. Paris: Editions Spes.

Le Bon, Gustaw. 1899. Psychologia tłumu. Tłumaczenie Zygmunt Poznański. Lwów-Warszawa: Księgarnia H. Altenberga.

Lecomte, Maxime. 1906. La Séparation des Églises et de l'État, histoire, principes, discussions, commentaires des articles de la loi du 9 décembre 1905. Paris: F. Juven.

Machlejd, Jerzy Artur. 1934. Rewolucja francuska $w$ świetle statystyki. Warszawa: Gebethner i Wolff .

Markow, Walter, i Albert Soboul. 1984. Wielka Rewolucja Francuzów 1789. Tłumaczenie Elke Morciniec. Wrocław: Zakład Narodowy im. Ossolińskich.

Mathieu, François-Désiré. 1903. Le Concordat de 1801: ses origines, son histoire, d'après des documents inédits. Paris: Perrin.

Mathiez, Albert. 1956. Rewolucja francuska. Tłumaczenie Władysław Dzwonkowski, Witold Łukaszewicz, i Tadeusz Landecki. Warszawa: Książka i Wiedza. 
Messlier, Jan. 1955. Testament. Tłumaczenie Zbigniew Bieńkowski. Warszawa: Państwowe Wydawnictwo Naukowe.

Mezzadri, Luigi. 2007. Rewolucja francuska a Kościót. Tłumaczenie Ewa Łukaszyk. Kraków: Wydawnictwo WAM. Księża Jezuici.

Misermont, Lucien. 1917. Le Serment 268 la constitution civile du clerg? Le serment civique et quelques documents inédits des archives vaticanes. Paris: Libraire Victor Lecoffre.

Nowak, Jerzy Robert. 1999. Kościót a rewolucja francuska. Szczecinek: Fundacja Nasza Przyszłość.

Pelczar, Józef Sebastian. 1922. Rewolucja francuska wobec religii katolickiej i jej duchowieństwa. Przemyśl: Nakładem autora.

Plongeron, Bernard. 1969. Conscience religieuse en Révolution. Regards sur l'historiographie religieuse de la Revolution française. Paris: A. \& J. Picard.

Potocki, Wacław. 1907. Ogród fraszek. T. 1. Lwów: Towarzystwo dla Popierania Nauki Polskiej.

Rogier, Luis J., Guillaume Bertier de Sauvigny, i Joseph Hajjar. 1987. Historia Kościoła. T. IV (1715-1858). Tłumaczenie Tadeusz Szafrański. Warszawa: Instytut Wydawniczy Pax.

Rousseau, Jan Jakub. 1920. Umowa społeczna. Tłumaczenie Antoni Peretiatkowicz. Poznań: Wydawnictwo Marek Derewiecki.

Rudé, George. 1966. Revolutionary Europe 1783-1815. New York: Harper \& Row.

Sagnac, Philippe. 1906. "Etude statistique sur le clergé constitutionnel et le clergé réfractaire en 1791." Revue d'Histoire Moderne \& Contemporaine 2:97-115.

Sagnac, Philippe. 1921. "La Révolution (1789-1792)." In Ernest Lavisse, Histoire de France contemporaine: depuis la Révolution jusqu'à la paix de 1919, vol. 1, 184-96. Paris: Hachette.

Sciout, Ludovic. 1872-1881. Histoire de la Constitution civile du clergé (1790-1801). Vol. 1. Paris: Firmin-Didot.

Scurr, Ruth. 2008. Robespierre. Terror $w$ imię cnoty. Tłumaczenie Barbara Przybyłowska. Warszawa: Wydawnictwo „Amber”.

Seidler, Grzegorz Leopold. 1984. Z zagadnień filozofii prawa: prawa i idee. Lublin: Wydawnictwo Lubelskie.

Sitarz, Mirosław, Michał Grochowina, Mariola Lewicka, Agnieszka Romanko, i Piotr Wierzbicki, red. 2012. Kościelne prawo publiczne. Wybór źródeł. Lublin: Wydawnictwo KUL.

Leskiewicz, Janina, i Jerzy Michalski, wyd. 1954. Supliki chłopskie XVIII wieku $z$ Archiwum Prymasa Michała Poniatowskiego. Warszawa: Książka i Wiedza.

Szelągowski, Adam. 1927. Rok 1789. Monarchia a rewolucja. Warszawa: Biblioteka Dzieł Wyborowych.

Szelągowski, Adam. 1934. Rewolucja francuska 1789-1793. Lwów: Wydawnictwo „Filomata”.

Tarle, Eugeniusz. 1946. Napoleon. Tłumaczenie Helena Winawerowa. Warszawa: Spółdzielnia Wydawnicza „Wiedza”.

Thompson, James Matthew. 1937a. Robespierre. T. 1, Od urodzenia Robespierre'a do śmierci Ludwika XVI. Tłumaczenie Aleksander Dobrot. Warszawa: Wydawnictwo J. Przeworskiego. 
Thompson, James Matthew. 1937b. Robespierre. T. 2, Od śmierci Ludwika XVI do śmierci Robespierre'a. Tłumaczenie Aleksander Dobrot. Warszawa: Wydawnictwo J. Przeworskiego.

Wasilewicz, Urszula. 2013. „Organizacja i funkcjonowanie Kościoła we francuskim porządku prawnym. Zarys problematyki.” Kościót i Prawo 2 (15): 197-208.

Wasilewicz, Urszula. 2017. Systemy relacji między Kościołem Katolickim i Francją. Studium historyczno-prawne. Lublin: Stowarzyszenie Absolwentów i Przyjaciół Wydziału Prawa Katolickiego Uniwersytetu Lubelskiego.

Wajs, Hubert. 1986. Powinno i feudalne chłopów na Mazowszu od XIV do poczatku XVI wieku ( $w$ dobrach monarszych $i$ ko ielnych). Wrocław: Zakład Narodowy im. Ossolińskich.

Weber, Max. 2002. Gospodarka i społeczeństwo. Zarys socjologii rozumiejacej. Tłumaczenie Dorota Lachowska. Warszawa: Wydawnictwo Naukowe PWN.

Wolter. 1960. Księżniczka Babilonu. Tłumaczenie Julian Rogoziñski. Warszawa: Pañstwowy Instytut Wydawniczy.

Zieliński, Zygmunt. 1993. Epoka rewolucji i totalitaryzmów. Studia i szkice. Lublin: Redakcja Wydawnictw KUL.

Żywczyński, Mieczysław. 1951. Kościót i rewolucja francuska. Warszawa: Instytut Wydawniczy Pax.

\section{Reformy organizacji Kościoła rzymskokatolickiego we Francji w latach 1789-1791}

Streszczenie

Przedmiotem niniejszej analizy jest proces reform w zakresie organizacji Kościoła rzymskokatolickiego we Francji, jakie przeprowadzono w pierwszym okresie Rewolucji, kiedy to Zgromadzenie Narodowe podjęło się próby etatyzacji Kościoła. W okresie tym nie występują jeszcze oznaki jawnej dechrystianizacji i ateizacji. Reformy parlamentarne dotyczą spraw organizacyjnych, majątkowych i osobowych Kościoła, których zwieńczeniem było uchwalenie konstytucji cywilnej duchowieństwa w dniu 12 lipca 1790 r., co pociągnęło jednakże za sobą wzrost niezadowolenia duchowieństwa, które popierało do tego czasu dotychczasowe przemiany, oraz doprowadziło do rozłamu i podziału wewnątrz łona organizacji kościelnej. Ustawodawstwo w sprawach kościelnych spotkało się z potępieniem ze strony papieża Piusa VI i spowodowało wzrost nastrojów antyrewolucyjnych szczególnie na prowincji. W trakcie analizy autor nieraz korzysta dla celów poznawczych z metody porównawczej, przywołując rozwiązania w zakresie stosunków wyznaniowych wprowadzone w kolejnych latach Rewolucji i rządów Napoleona, które modyfikowały omówione rozwiązania będące właściwym przedmiotem badań.

Słowa kluczowe: Rewolucja francuska; etatyzacja Kościoła; konstytucja cywilna duchowieństwa 


\section{Reforms of the Organisation of the Roman \\ Catholic Church in France in 1789-1791}

Sum mary

The article examines the process of reforms in the organisation of the Roman Catholic Church in France, which were implemented during the first period of the Revolution, when the National Assembly made an attempt at introducing state control (étatisation) of the Church. At this time, no signs of overt dechristianisation and atheisation could be seen. The parliamentary reforms affected the organisational, property, and personal affairs of the Church, and culminated in the adoption of the Civil Constitution of the Clergy on 12 July 1790. However, this increased the dissatisfaction of the clergy, who hereto had supported the transformations, and caused a rift within the Church. The legislation on ecclesiastical matters was condemned by Pope Pius VI and caused an increase in anti-revolutionary sentiments, especially locally. The author makes a frequent use of the comparative method for reference only, invoking the solutions used in the area of religious relations in the subsequent years of the Revolution and Napoleon's rule. These solutions modified the ones discussed in detail in the article.

Key words: French Revolution; étatisation; Civil Constitution of the Clergy

Information about Author: MARCIN KoNARSKI, PH.D. - associate professor, Department of Administration, Faculty of Social Sciences and Administration at the Warsaw Management University; ul. Kawęczyńska 36, 03-772 Warszawa, Poland; e-mail: marcin.konarski@wsm.warszawa.pl; https://orcid.org/0000-0001-8791-884X 